\title{
Molecular survey of Cryptosporidium spp. in calves from the state of Mato Grosso, Brazil
}

\section{Levantamento molecular de Cryptosporidium spp. em bezerros do estado de Mato Grosso, Brasil}

\author{
Thábata dos Anjos Pacheco하 Felippe Danyel Cardoso Martins²; Sayanne Luns \\ Hatum de Almeida ${ }^{1}$; Thiago Borges Fernandes Semedo ${ }^{3}$; Michelle Igarashi \\ Watanabe ${ }^{4}$; Valéria Dutra ${ }^{5}$; João Luis Garcia ${ }^{6}$; Richard de Campos Pacheco ${ }^{5 *}$
}

\section{Highlights:}

The first molecular characterization of Cryptosporidium spp. in the state of Mato Grosso.

The first identification of zoonotic subtypes of Cryptosporidium parvum in calves from the state.

The first detection of the subtype IIaA16G3R1 of Cryptosporidium parvum in South America.

\begin{abstract}
Cryptosporidium spp. is a protozoan that infects a wide range of vertebrate hosts; it has been reported to be the cause of severe illness or death in livestock worldwide, which leads to decreased performance and production losses, especially in young animals. This study investigated the presence of Cryptosporidium in calves from beef farms in the state of Mato Grosso, midwestern Brazil. For this purpose, fecal samples from 237 animals aged $\leq 45$ days, raised in 20 rural properties were subjected to DNA extraction and nested polymerase chain reaction (nPCR) targeting 18S ribosomal RNA (18S rRNA) gene followed by sequencing. Additionally, positive samples, previously identified as Cryptosporidium parvum by sequencing and phylogenetic analyses based on $18 \mathrm{~S}$ rRNA gene, were subsequently analyzed focusing the amplification and sequencing using nPCR of a fragment of the $60 \mathrm{kDa}$ glycoprotein (gp60) gene. Of the 237 fecal samples analyzed by PCR (18S rRNA), 50 (21.1\%) fecal samples were positive for Cryptosporidium spp., while $14(70 \%)$ of the 20 properties had at least one positive animal. The following Cryptosporidium species were detected: C. bovis, C. parvum, and C. ryanae. Thereafter, two potentially zoonotic subtypes (IIaA15G2R1 and IIaA16G3R1) of C. parvum were identified based on gp60 gene sequences. This study resulted in the detection of subtype IIaA16G3R1 for the first time in South America and showed a wide distribution of the protozoan in beef farms in the studied area of the State.
\end{abstract}

Key words: Calf. Cryptosporidium parvum. Feces. Zoonosis.

1 Discentes do Curso de Doutorado, Programa de Pós-Graduação em Ciências Veterinária, Faculdade de Medicina Veterinária, Universidade Federal do Mato Grosso, UFMT, Cuiabá, MT, Brasil. E-mail: thabatapacheco@gmail.com; sayhatum@gmail.com

2 Discente do Curso de Doutorado, Programa de Pós-Graduação em Ciência Animal, Departamento de Medicina Veterinária Preventiva, Universidade Estadual de Londrina, UEL, Londrina, PR, Brasil. E-mail: felippemartins@hotmail.com

3 Pesquisador, M.e, Programa de Capacitação Institucional, Museu Paraense Emílio Goeldi, Instituto Nacional de Pesquisa do Pantanal, INPP, Cuiabá, MT, Brasil. E-mail: thiagosemedo@gmail.com

4 Prof $^{a}$ Dra $^{\text {a }}$ Departamento de Ciências Básicas em Saúde, Faculdade de Medicina, UFMT, Cuiabá, MT, Brasil. E-mail: michelle. igarashi@gmail.com

5 Profs. Drs., Programa de Pós-Graduação em Ciências Veterinária, UFMT, Cuiabá, MT, Brasil. E-mail: valdutra@ufmt.br; richard@ufmt.br

6 Prof. Dr., Programa de Pós-Graduação em Ciência Animal, Departamento de Medicina Veterinária Preventiva, Centro de Ciências Agrárias, UEL, Londrina, PR, Brasil. E-mail: joaoluisgarcia10@gmail.com

* Author for correspondence 


\section{Resumo}

Cryptosporidium spp. é um protozoário que infecta uma grande variedade de hospedeiros vertebrados, sendo descrito como causa de doenças graves ou morte na pecuária em todo o mundo, o que leva à diminuição do desempenho e à perda de produção, especialmente em animais jovens. Este estudo investigou a presença de Cryptosporidium em bezerros de fazendas de bovinocultura de corte no estado de Mato Grosso, Centro-Oeste do Brasil. Para esse fim, amostras fecais de 237 animais com idade $\leq 45$ dias, criados em 20 propriedades rurais foram submetidas à extração de DNA e uma "nested" da reação em cadeia pela polimerase (nPCR) direcionada ao gene 18S RNA ribossomal (18S rRNA), seguido do sequenciamento. Adicionalmente, amostras positivas, previamente identificadas como Cryptosporidium parvum pelo sequenciamento e análises filogenéticas baseadas no gene $18 \mathrm{~S}$ rRNA, foram posteriormente analisadas usando a nPCR buscando a amplificação e sequenciamento de um fragmento do gene de uma glicoproteína de $60 \mathrm{kDa}$ (gp60). Das 237 amostras fecais analisadas pela PCR (18S rRNA), 50 (21,1\%) amostras fecais foram positivas para Cryptosporidium spp., enquanto 14 (70\%) das 20 propriedades tinham ao menos um animal positivo. As seguintes espécies de Cryptosporidium foram detectadas: $C$. bovis, C. parvum e C. ryanae. Posteriormente, dois subtipos potencialmente zoonóticos (IIaA15G2R1 e IIaA16G3R1) foram identificados. Este estudo resultou na detecção do subtipo IIaA16G3R1 pela primeira vez na América do Sul e mostrou uma ampla distribuição do protozoário em rebanhos de corte na área estudada do Estado.

Palavras-chave: Bezerro. Cryptosporidium parvum. Fezes. Zoonose.

The genus Cryptosporidium comprises protozoan parasites that belongs to the Apicomplexa phylum, and recently their classification has been discussed; it has been reclassified as gregarine (class Gregarinomorphea, subclass Cryptogregaria), which is composed solely of species of this genus (Cavalier-Smith, 2014).

Occurrence of cryptosporidiosis in cattle have been described worldwide, and infections in young animals are frequently associated with morbidity, and sometimes mortality, and these calves are known to harbor zoonotic species, representing a potential public health risk. Cattle are hosts of different species of the genus Cryptosporidium including C. parvum, C. bovis, C. ryanae, and $C$. andersoni (Robertson, Björkman, Axén, \& Fayer, 2014), with C. parvum being recognized for its zoonotic potential (Trotz-Williams et al., 2006).

Despite some molecular researches of Cryptosporidium in cattle have been described in Brazil (Toledo et al., 2017; Holsback et al., 2018), studies concerning Cryptosporidium infection are scarce in the state, with only one published research based on parasitological examination for the detection of oocysts, with no identification at the species level, nor molecular characterization of the protozoan (Oliveira et al., 2007).

Once beef cattle farming is one of the most important economic activities in the state of Mato Grosso, and the state is one of Brazil's largest meat exporter, the present study molecularly investigated the presence of Cryptosporidium in calves' feces in beef cattle herds from the state of Mato Grosso, midwestern Brazil.

During January to August 2016, fresh stool samples from 237 crossbred and zebu calves aged $\leq 45$ days, without signs of diarrhea, were randomly collected from 20 beef herds in 15 municipalities of the state of Mato Grosso, Brazil (Figure 1). Fecal samples were kept refrigerated until the analysis, which was performed within $24 \mathrm{~h}$.

All procedures were approved (protocol number 23108.151952/2016-63) by the Animal Research Ethics Committee of the Federal University of Mato Grosso (UFMT), Brazil. 
Fecal samples were submitted to DNA extraction using NucleoSpin ${ }^{\circledR} \quad$ Tissue Commercial Kit (Macherey-Nagel, Düren, Germany), following the manufacturer protocol with an increment of three cycles of freezing in liquid nitrogen and thawing at $56^{\circ} \mathrm{C}$ before lysis.

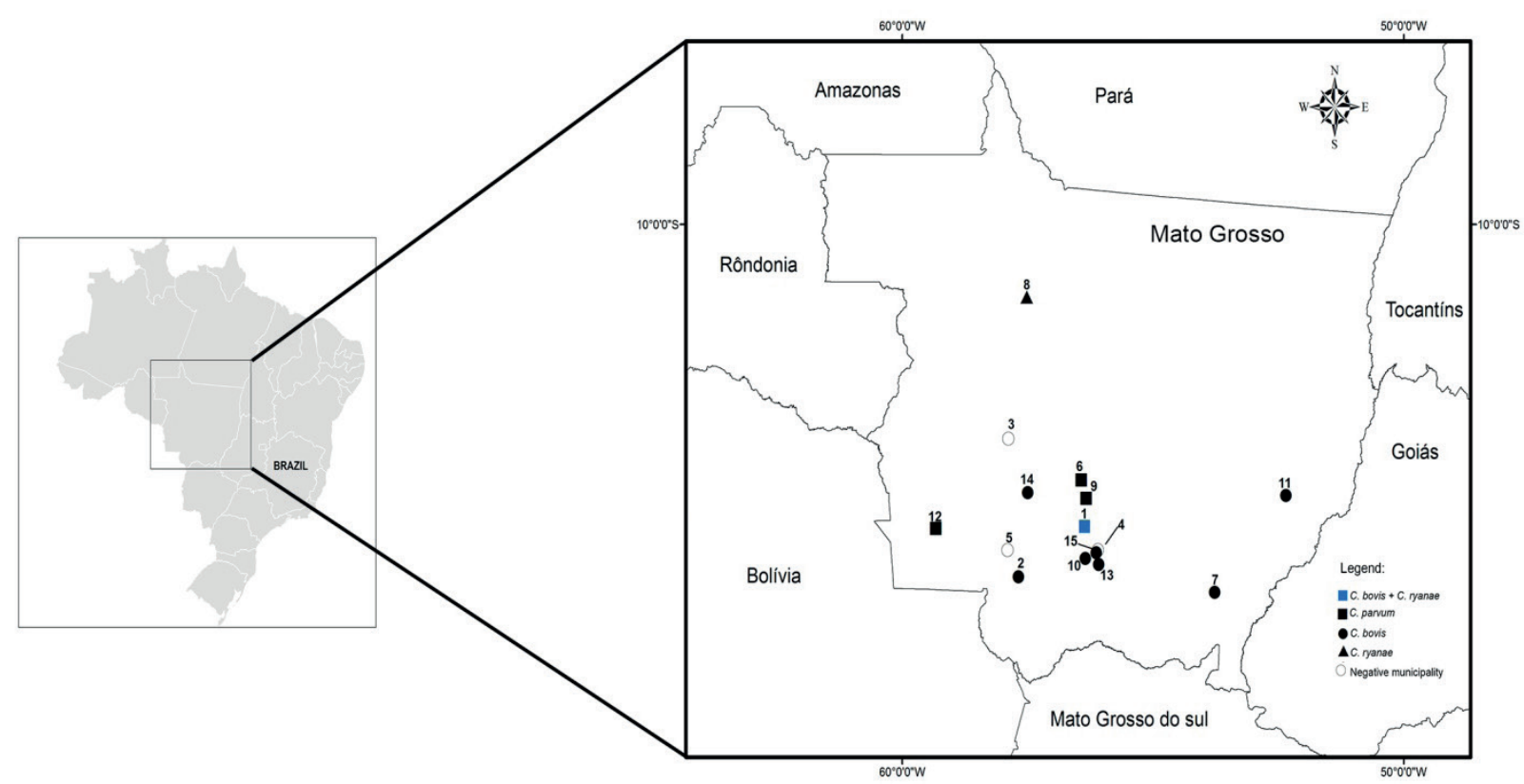

Figure 1. Spatial distribution and Cryptosporidium species identified in beef herd distributed through 15 municipalities in the state of Mato Grosso, Brazil.

1- Acorizal; 2- Cáceres; 3- Campo Novo dos Parecis; 4- Cuiabá; 5- Curvelândia; 6- Diamantino; 7- Guiratinga; 8- Juara; 9- Nobres; 10- Nossa Senhora do Livramento; 11- Nova Xavantina; 12- Pontes e Lacerda; 13- Santo Antônio do Leverger; 14- Tangará da Serra; 15- Várzea Grande.

Firstly, DNA samples were screened using a nested Polimerase Chain Reaction (nPCR) targeting a 826 to 864-base pair (bp) fragment of the $18 \mathrm{~S}$ ribosomal RNA (18S rRNA) gene of Cryptosporidium, as previously described (Xiao et al., 1999). Nuclease free water and DNA from C. parvum (GenBank: KX929939) obtained from naturally infected dairy cattle were used as negative and positive controls, respectively. The amplified product was subjected to $1.5 \%$ agarose gels stained with the GelRed ${ }^{\mathrm{TM}}$ Nucleic Acid Gel Stain (Biotium, Fremont, California) and visualized in a ChemiDoc XRS system (Bio-Rad, Hercules, California). Amplicons of the positive samples were purified using the Illustra GFX PCR DNA and Gel Band Purification Kit (GE Healthcare, Chicago, Illinois) for sequencing with the BigDye ${ }^{\mathrm{TM}}$ kit (Applied
Biosystems, Foster, California). Sequencing was performed using the automated sequencer (ABI-PRISM 3500 Genetic Analyzer, Applied Biosystems, Foster, California), according to the manufacturer's instructions, with the same primers used in the second reaction of the nPCR.

The sequences obtained were visualized and aligned for contig assembly in the program Geneious ${ }^{\circledR} 7.1 .3$ software for sequence data analysis, and later edited and aligned manually in the program BioEdit 7.0.5.2. Genetic distances within and between groups obtained from the phylogenetic analyses were then calculated based on the Kimura-2- Parameters K2P (Kimura, 1980) model using tools of MEGA software v6.0 (Tamura, Stecher, Peterson, Filipski, \& Kumar, 2013). Phylogenetic analyses were performed 
using MEGA v6.0 (Tamura et al., 2013) with 1000 replicates of bootstrap and the consensus tree was constructed by means of the neighbor-joining (NJ) method with bootstrap values above $95 \%$.

Positive samples, previously identified as $C$. parvum by phylogenetic analyses based on $18 \mathrm{~S}$ rRNA gene, were submitted to nPCR amplification targeting a fragment $(832 \mathrm{bp}$ ) of the $60-\mathrm{kDa}$ glycoprotein (gp60) gene, as previously described (Toledo et al., 2017). PCR products of positive samples for gp60 gene were purified and sequenced, as previously detailed, in order to reveal the subtype of C. parvum isolates.

Among 237 tested samples, 50 (21.10\%) were positive for the 18S rRNA gene, and 70\% (14/20) sampled farms had at least one positive animal using the same criteria. After analysis of the sense and antisense sequences, all 50 partial consensus sequences of the $18 \mathrm{~S}$ rRNA obtained were used to construct the phylogenetic tree and then to perform phylogenetic analysis. Figure 2 shows that Cryptosporidium isolates were segregated into the following three species: C. bovis, C. ryanae, and C. parvum; the greatest genetic distance $(0.043)$ was observed between $C$. parvum and $C$. ryanae. GenBank accession numbers for all sequences used to perform the phylogenetic analyses were embedded in the phylogenetic tree (Figure 2).

Among 50 of these 18s rRNA-nPCR positive fecal samples, $C$. bovis was the most common species identified $(54 \% ; 27 / 50)$, followed by C. parvum $(24 \% ; 12 / 50)$, and C. ryanae $(22 \%$; 11/50). GenBank accession number for the partial sequences of 18S rRNA gene generated for C. bovis, C. parvum, and C. ryanae in the present study are MH478527-MH478553, MH477694-MH477705, and MH474547-MH474557, respectively.

The spatial distribution of Cryptosporidium species identified in the municipalities included in the present study is shown in Figure 1. Noteworthy, Cryptosporidium DNA was not detected in the tested fecal samples from Campo Novo dos Parecis (eight samples), Cuiabá (11 samples), and Curvelândia (six samples) municipalities. Furthermore, the rate of infection in each municipality, as determined by the presence of Cryptosporidium species, was as follows (no. infected/no. tested): C. bovis was identified in $6.52 \%(3 / 46), 20 \%(1 / 5), 41.17 \%$ (7/17), 4.76\% (1/21), 12.5\% (3/24), 38.1\% (8/21), and $22.22 \%(2 / 9)$ of tested fecal samples from the municipalities of Cáceres, Guiratinga, Nossa Senhora do Livramento, Nova Xavantina, Santo Antônio do Leverger, Tangará da Serra and Várzea Grande, respectively; C. parvum was identified in Diamantino, Nobres, and Pontes e Lacerda municipalities, with the rate of infection among calves being $88.9 \%(8 / 9), 20 \%(3 / 15)$, and $12.5 \%$ (1/8), respectively; C. ryanae was detected in $20 \%$ $(1 / 5)$ of tested samples from Juara; in addition, two species (C. bovis and C. ryanae) were identified in $6.25 \%(2 / 32)$ and $31.25 \%(10 / 32)$ of fecal samples tested in the Acorizal municipality.

Because of the quality of and insufficient DNA quantity in the amplified samples, based on faint band denoting positive nPCR but insufficient amplicon concentration for sequencing, it was possible to sequence gp60 gene amplicons from only 11 C. parvum-nPCR positive samples. The subtype IIaA15G2R1 was identified in three fecal samples from a farm located in the municipality of Nobres, whereas subtype IIaA16G3R1 was identified in DNA samples of eight animals raised in the same beef farm from Diamantino municipality. GenBank accession numbers for all partial sequences of gp60 gene generated in the present study are MH511478 - MH511486 and MN019011-MN019012.

The most common Cryptosporidium species found infecting bovines includes the following: C. parvum, C. bovis, C. ryanae, and C. andersoni (Robertson et al., 2014), corroborating the data observed in the present study, with the exception that $C$. andersoni was not detected, possibly because this species is often found in older animals (Silverlås, de Verdier, Emanuelson, Mattsson, \& Björkman, 2010). 


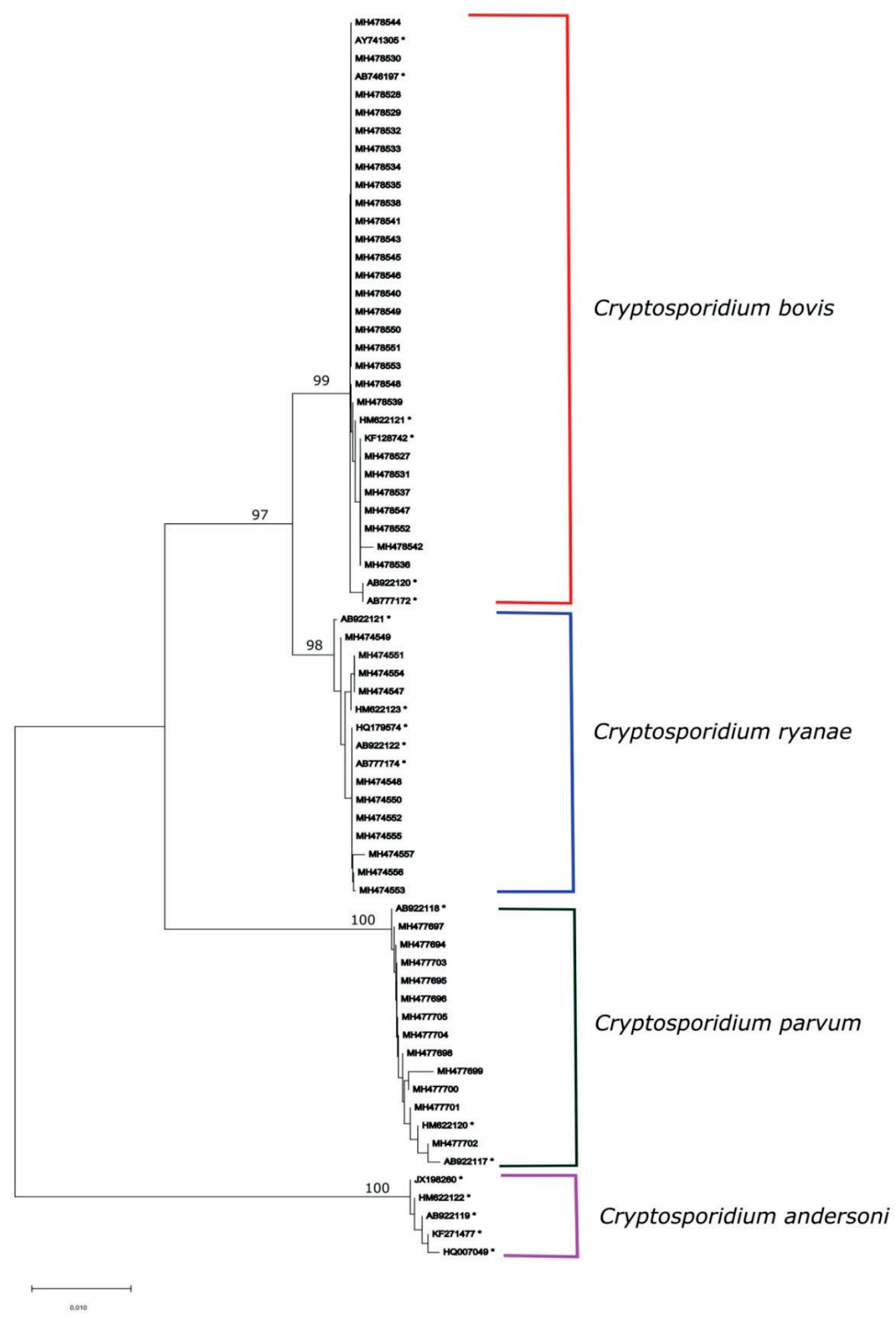

Figure 2. Phylogenetic tree constructed from sequences of $18 \mathrm{~S}$ rRNA gene with 705 bp of Cryptosporidium species. The neighbor-joining (NJ) analysis was performed with bootstrap values of above $95 \%$ and the nodes displayed based on 79 specimens K2P distance. (*) Sequences obtained from Genbank that were used for comparisons with the sequences obtained in the present study include AB922120, AB777172, AB746197, KF128742, HM622121, AY741305, AB922121, AB922122, HQ179574, AB777174, HM622123, HM622120, AB922117, AB922118, HM622122, AB922119, KF271477, HQ007049, and JX198260. 
Studies have described infection by Crypstosporidium in cattle and herd from Brazil (Oliveira et al., 2007; Toledo et al., 2017; Holsback et al., 2018), and these studies reported different prevalence compared to that reported in the present study. The rate of infection with Cryptosporidium spp. among cattle may vary widely due to age and animal husbandry, among other factors. Toledo et al. (2017) observed a significantly higher occurrence of Cryptosporidium spp. in calves (up to 6 months of age) than in older animals. On the other hand, it is expected that in dairy calves, which are commonly confined, the infection is more common compared to beef calves, which are kept in more open areas (McAllister, Olson, Fletch, Wetzstein, \& Entz, 2005), such as the calves included in the present study. In this context, Holsback et al. (2018) have reported that dairy calves were 2.66 times more likely to be infected with Cryptosporidium than beef calves from Paraná state, Southern Brazil.

Furthermore, the infection rate observed in the present study $(21.10 \%)$ was higher when compared with that observed in the study conducted by Oliveira et al. (2007), among apparently healthy calves $(10 \%)$ from beef calves in the state of Mato Grosso. However, Oliveira et al. (2007) have analyzed only 30 non-diarrheic animals being all of them from a single, and a notably large rural property (with 30,000 hectares of pasture), while the present study evaluated an expressive number of animals encompassing 20 different rural properties from 15 municipalities in the state of Mato Grosso. In addition, the daily excretion of oocysts in animal feces is characterized by irregularity and heterogeneous distribution and according to Brook, Hart, French and Christley (2008), so the results of prevalence studies vary widely depending on the sensitivity and specificity of the screening methods used and the sampled management groups sampled.

The most common species identified in the calves from the analyzed beef farms was $C$. bovis, followed by C. parvum and C. ryanae. In general, younger calves of a similar age group as animals sampled in this study (aged $<8$ weeks) are reported most likely to be shedding C. parvum, while older calves may shed C. bovis and C. ryanae (Robertson et al., 2014). However, our results corroborate with those of studies in other countries, such as the report of $C$. bovis being the most prevalent species in beef calves from Sweden, as well as, early excretion of $C$. bovis and $C$. ryanae by animals ( $\leq 2$ months old) (Silverlås et al., 2010). These differences and variations in species infecting animals of the same age range may be related to the aspects of farms and of the animals and suggests that the agespecies relationship is not fully understood (Rieux, Paraud, Pors, \& Chartier, 2014), in this sense, future studies are needed including epidemiological data and productive characteristics of beef farms in order to obtain more in-depth knowledge of the epidemiology of cryptosporidiosis in cattle in the state of Mato Grosso.

Regarding pathogenicity, although fecal samples are from non-diarrheic calves, the three Cryptosporidium species found are potentially pathogenic, since $C$. bovis has been reported in diarrheal samples obtained from calves aged $>$ 21 days in Sweden (Silverlås, Bosaeus-Reineck, Näslund, \& Björkman, 2013), while C. parvum is the most pathogenic species, and the most frequently diagnosed cause of diarrhea in calves worldwide (Silverlås et al., 2013; Robertson et al., 2014). On the other hand, C. ryanae has been considered minor pathogenic (Robertson et al., 2014).

Genetic diversity from PCR-positive samples of C. parvum for the gp60 gene resulted in two potentially zoonotic subtypes belonging to family IIa: IIaA15G2R1 and IIaA16G3R1. The subtype IIaA15G2R1 has been shown to be more prevalent among humans and animals in several countries and comprises the highly zoonotic subtype, with young cattle as the main reservoir (Xiao, 2010).

The present study reports the first detection of the subtype IIaA16G3R1 of C. parvum in South America. The subtype has been observed more 
frequently in other continents (Trotz-Williams et al., 2006; Razakandrainibe et al., 2018). Moreover, the aforementioned subtype has been reported to cause human infection (Trotz-Williams et al., 2006) and associated with clinical episodes such as digestive symptoms, respiratory symptoms, and an impaired or poor general state in calves (Razakandrainibe et al., 2018).

In conclusion, the molecular data presents a broad distribution of Cryptosporidium infection among asymptomatic beef calves from the state of Mato Grosso, Brazil, resulting in the identification of three species of Cryptosporidium within animals, namely $C$. bovis, $C$. parvum and $C$. ryanae. In addition, apparently healthy calves were observed harboring two zoonotic subtypes of C. parvum, which might be the cause of human infections.

\section{Acknowledgments}

The authors gratefully acknowledge Ranoock Luã Alves Victor De Matos and Rafael Moraes de Assis for their valuable help during field sampling of calves. This work was supported by the Brazilian funding agency Fundação de Amparo à Pesquisa do Estado de Mato Grosso - FAPEMAT (grants \#155680/2014), by Instituto Federal de Rondônia (IFRO) for the qualification incentive program (PIC) and financial contribution as incentive to T.A. Pacheco, and Coordenação de Aperfeiçoamento de Pessoal de Nível Superior - CAPES for the grant of a scholarship to F. D. C. Martins. J. L. Garcia, R. C. Pacheco, and V. Dutra are in receipt of productivity scholarships from Conselho Nacional de Desenvolvimento Científico e Tecnológico (CNPq).

\section{References}

Brook, E., Hart, C. A., French, N., \& Christley, R. (2008). Prevalence and risk factors for Cryptosporidium spp. infection in young calves. Veterinary Parasitology, 152(1-2), 46-52. doi: 10.1016/j.vetpar.2007.12. 003
Cavalier-Smith, T. (2014). Gregarine site-heterogeneous $18 \mathrm{~S}$ rDNA trees, revision of gregarine higher classification, and the evolutionary diversification of Sporozoa. European Journal of Protistology, 50(5), 472-495. doi: 10.1016/j.ejop.2014.07.002

Holsback, L., Lima, H. E., Vidotto, O., Silva, M. A. D., Patelli, T. H. C., \& Martins, F. D. C. (2018). Cryptosporidium occurrence in ruminants from the North Pioneer mesoregion of Paraná, Brazil. Revista Brasileira de Parasitologia Veterinária, 27(2), 248253. doi: 10.1590/S1984-296120180037

Kimura, M. (1980). A simple method for estimating evolutionary rates of base substitutions through comparative studies of nucleotide sequences. Journal of Molecular Evolution, 16(2), 111-120. doi: 10. 1007/BF01731581

McAllister, T. A., Olson, M. E., Fletch, A., Wetzstein, M., \& Entz, T. (2005). Prevalence of Giardia and Cryptosporidium in beef cows in southern Ontario and in beef calves in southern British Columbia. Canadian Veterinary Journal, 46(1), 47-55. doi: 10.4141/cjas66-008

Oliveira, J. P., F., Silva, D. P. G., Pacheco, M. D., Mascarini, L. M., Ribeiro, M. G., Alfieri, A. A. Borges, A.,... S. (2007). Diarréia em bezerros da raça Nelore criados extensivamente: estudo clínico e etiológico. Pesquisa Veterinária Brasileira, 27(10), 419-424. doi: 10.1590/S0100-736X2007001000006

Razakandrainibe, R., Diawara, E. H. I., Costa, D., Le Goff, L., Lemeteil, D., Ballet, J. J.,... Favennec, L. (2018). Common occurrence of Cryptosporidium hominis in asymptomatic and symptomatic calves in France. PLoS Neglected Tropical Diseases, 12(3), e0006355. doi: 10.1371/journal.pntd.0006355

Rieux, A., Paraud, C., Pors, I., \& Chartier, C. (2014). Molecular characterization of Cryptosporidium isolates from beef calves under one month of age over three successive years in one herd in western France. Veterinary Parasitology, 202(3-4), 171-179. doi: 10.1016/j.vetpar.2014.03.004

Robertson, L. J., Björkman, C., Axén, C., \& Fayer, R. (2014). Cryptosporidium: parasite and disease. In S. M. Caccio, \& G. Widmer (Eds.), Cryptosporidium: parasite and disease (pp. 149-235). Wien: SpringerVerlag.

Silverlås, C., Bosaeus-Reineck, H., Näslund, K., \& Björkman, C. (2013). Is there a need for improved Cryptosporidium diagnostics in Swedish calves? International Journal of Parasitology, 43(2), 155161. doi: 10.1016/j.ijpara.2012.10.009 
Silverlås, C., de Verdier, K., Emanuelson, U., Mattsson, J. G., \& Björkman, C. (2010). Cryptosporidium infection in herds with and without calf diarrheal problems. Parasitology Research, 107(6), 14351444. doi: 10.1007/s00436-010-2020-x

Tamura, K., Stecher, G., Peterson, D., Filipski, A., \& Kumar, S. (2013). MEGA6: molecular evolutionary genetics analysis version 6.0. Molecular Biology and Evolution, 30(12), 2725-2729. doi: 10.1093/ molbev/mst197

Toledo, R. D., Martins, F. D., Ferreira, F. P., Almeida, J. C., Ogawa, L., Santos, H. L. dos,... Freire, R. L. (2017). Cryptosporidium spp. and Giardia spp. in feces and water and the associated exposure factors on dairy farms. PLoS One, 12(4), e0175311. doi: 10.1371/journal.pone.0175311
Trotz-Williams, L. A., Martin, D. S., Gatei, W., Cama, V., Peregrine, A. S., Martin, S. W.,... Xiao, L. (2006). Genotype and subtype analyses of Cryptosporidium isolates from dairy calves and humans in Ontario. Parasitology Research, 99(4), 346-352. doi: 10.1007/s00436-006-0157-4

Xiao, L. (2010). Molecular epidemiology of cryptosporidiosis: an update. Experimental Parasitology, 124(1), 80-89. doi: 10.1016/j. exppara.2009.03.018

Xiao, L., Morgan, U. M., Limor, J., Escalante, A., Arrowood, M., Shulaw, W.,... Lal, A. A. (1999). Genetic diversity within Cryptosporidium parvum and related Cryptosporidium species. Applied Environment Microbiology, 65(8), 3386-3391. 